\title{
ДОСВІД ВПРОВАДЖЕННЯ ІНФОРМАЦІЙНО-КОМУНІКАЦІЙНИХ ТЕХНОЛОГІЙ В НАВЧАЛЬНОМУ ПРОЦЕСІ БУКОВИНСЬКОГО ДЕРЖАВНОГО МЕДИЧНОГО УНІВЕРСИТЕТУ
}

\author{
Т. М. Бойчук, І. В. Геруш, В. М. Ходоровський \\ Буковинський державний медичний університет \\ EXPERIENCE OF INTRODUCING INFORMATION AND \\ COMMUNICATION TECHNOLOGIES IN EDUCATIONAL PROCESS \\ AT BUKOVYNIAN STATE MEDICAL UNIVERSITY
}

\author{
T. M. Boychuk, I. V. Herush, V. M. Khodorovskyi \\ Bukovynian State Medical University
}

\begin{abstract}
У статті висвітлено досвід впровадження в Буковинському державному медичному університеті інформаційно-комунікаційних навчальних технологій на базі системи управління навчанням “Моodle". Використання такої технології підтримки традиційного навчального процесу дозволяс поліпшити його якість, робить його більш комфортним та цікавим для студента, більш контрольованим - для викладача.
\end{abstract}

\begin{abstract}
The article deals with the experience of Bukovynian State Medical University in introducing of information and communication educational technologies - based on learning management system "Moodle". The use of such technology in the maintaining of traditional educational process allows improving its quality, making it more comfortable and interesting for students, more supervised by teachers.
\end{abstract}

Вступ. Сучасне суспільство характеризується глобальним процесом інформатизації, стрімким переходом на новий етап розвитку - інформаційне суспільство [1]. Широка інформатизація суспільних процесів безпосередньо торкнулася і вищої освіти. У зв'язку із цим викладач та традиційні засоби навчання перестають бути для студента єдиним джерелом отримання знань, оскільки багато інформації можна знайти в мережі "Інтернет". Цьому сприяють також засади кредитно-модульної системи організації навчального процесу, а саме суттєве збільшення частки самостійної роботи студентів у навчальних програмах усіх дисциплін. Тому орієнтація на формування репродуктивних навичок, таких як запам'ятовування та відтворення за традиційного навчання, замінюється на розвиток умінь зіставлення, синтезу, аналізу, оцінювання виявлення зв'язків, планування, групової взаємодії з використанням мережевих інформаційно-комунікаційних технологій (IКТ) [2,3]. Впровадження сучасних IКТ у навчально-виховний процес визначено пріоритетним напрямком розвитку сучасної освіти України [4].

Серед IКТ найбільшого застосування набули спеціалізовані інформаційні системи, які називають системами управління навчанням (learning management system, LMS) або, інколи, програмно-педагогічними система- ми [5]. Такі системи використовують для управління змістом навчання та процесом навчання. Сьогодні $€$ доволі широкий спектр розроблених систем управління навчанням, які поширюються як на комерційній основі (WebCT, Blackboard, Microsoft Learning Gateway тощо), так і вільно (ATutor, OLAT, Sakai, Moodle).

Основна частина. У Буковинському державному медичному університеті для забезпечення студентів, лікарів(провізорів)-інтернів та лікарів-курсантів електронними навчальними матеріалами, організації та керування самостійною роботою, автоматизованого тестування впроваджено використання мережевих IKT навчання на базі LMS "Moodle".

Moodle (Modular Object-Oriented Dynamic Learning Environment) - віртуальне навчальне середовище або система управління навчанням, дистрибутив якої розповсюджується безкоштовно за принципами ліцензії Open Source. За допомогою цієї системи студент може дистанційно, через мережу "Інтернет” ознайомитися з навчальним матеріалом, який подається у вигляді різнотипних інформаційних ресурсів (текст, відео, анімація, презентація, електронний посібник), виконати завдання та відправити результати їх виконання на перевірку викладачу.

Впроваджено у навчальний процес Буковинського державного медичного університету (БДМУ) дану

() Т. М. Бойчук, I. В. Геруш, В. М. Ходоровський 
Матеріали Всеукраїнської навчально-наукової конференції, присвяченої 55-річчю Тернопільського державного медичного університету імені І. Я. Горбачевського, “Впровадження нових технологій за кредитно-модульної системи організації навчального процесу у ВМ(Ф)НЗ III-IV рівнів акредитації”

систему в 2010 році. Насамперед було вивчено правові, організаційно-методичні, наукові та технічні засади використання IКТ, на підставі чого розроблено відповідний план заходів.

Згідно з розробленим планом була досліджена технічна можливість експлуатації навчального інтернет-середовища "Moodle" студентами університету, для чого у вересні 2010 року було проведено відповідне анкетування. За результатами опитування встановлено, що майже у $70 \%$ студентів, які навчалися у той час в Буковинському державному медичному університеті, $\epsilon$ персональ- ний комп’ютер (ноутбук) і є можливість доступу до мережі "Інтернет". Такі результати анкетування дозволи зробити висновок, що більшість студентів матиме технічну можливість користуватися навчальним веб-контентом. Решта студентів у той час могла користуватися послугами 17 комп'ютерних класів університету.

У жовтні 2010 року було запущено сервер дистанційного навчання (moodle.bsmu.edu.ua), на якому було створено навігаційну карту в розрізі факультетів, спеціальностей (напрямів), курсів та навчальних дисциплін відповідно до робочих навчальних планів (рис. 1).

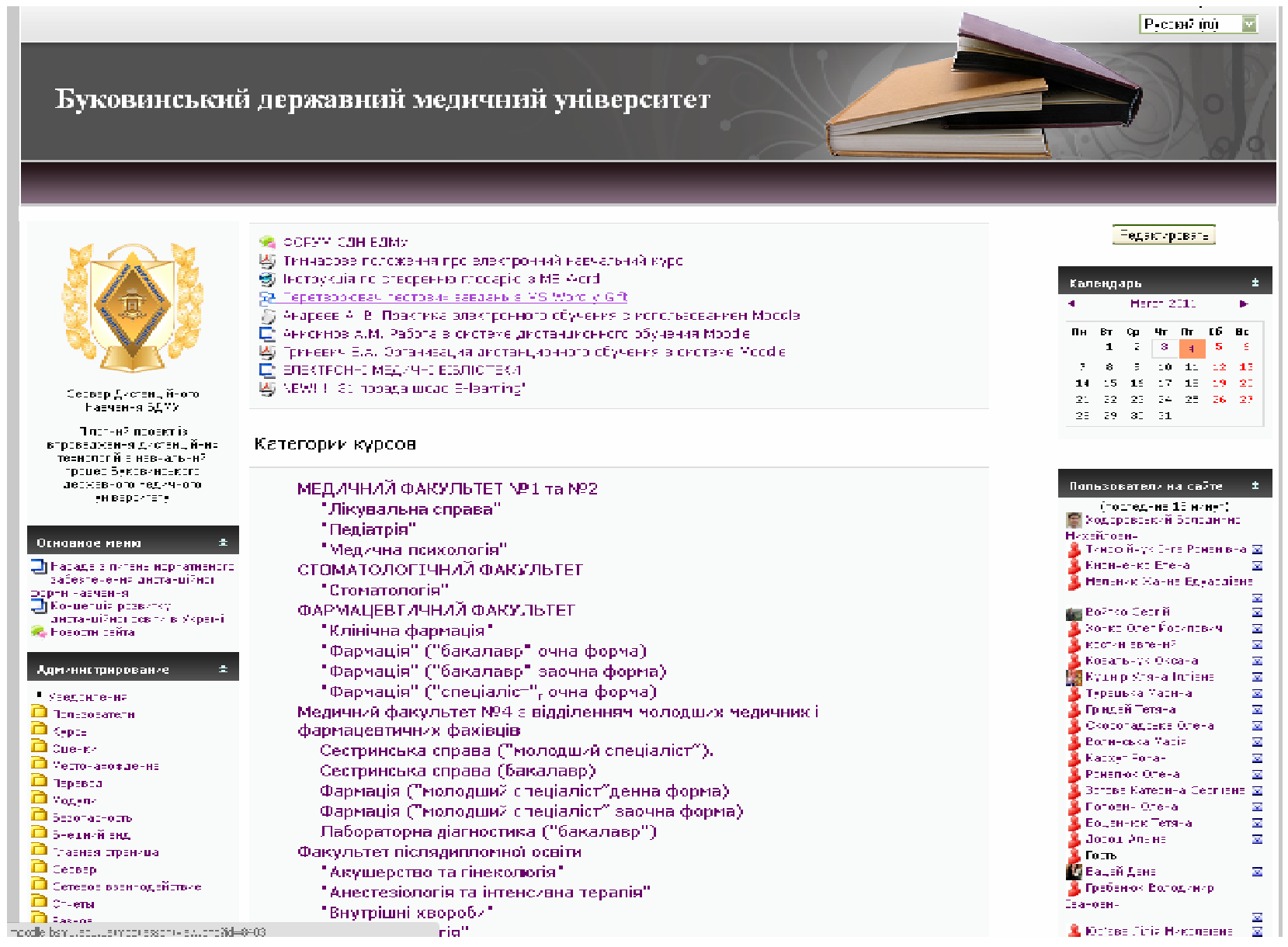

Puc. 1. Стартова сторінка сервера дистанційного навчання Буковинського державного медичного університету.

У листопаді 2010 року розроблено та затверджено вченою радою університету Тимчасове положення про електронний навчальний курс у середовищі “Moodle” на сервері дистанційного навчання БДМУ. Цим положенням було визначено структуру електронних навчальних курсів та вимоги до його складових. Складові частини електронного навчального курсу на СДН БДМУ містять такі навчально-методичні матеріали:

1. Загальна інформація про курс:

- довідник для студента з відповідної навчальної дисципліни, в якому зазначено структуру, мету, зміст дисципліни, принципи оцінювання, календарні та тематичні плани навчальних занять;

- графік відробіток та консультацій;

- глосарій (тлумачний словник) з навчальної дисципліни.

2. Тематичні розділи, які створюють відповідно до тематичного плану практичних (семінарських) занять 3 певної навчальної дисципліни, а також тем для самостійного вивчення, містять:

- методичні вказівки для студента для самостійної роботи під час підготовки до практичного заняття, в 
яких обов'язково зазначають актуальність теми, тривалість заняття, навчальну мету, питання для самоконтролю, список рекомендованої навчальної літератури;

- “конспекти" - структуровані електронні навчальні матеріали, зміст яких надає студенту теоретичні відомості з теми практичного (семінарського) заняття у повному обсязі;

- наочні матеріали (зображення - навчальні таблиці, мікрофотографіі, рентгенограми; відеоролики, анімація, аудіо, презентації тощо);

- тестові завдання для самоконтролю, які дають можливість студенту самостійно пройти тестування у режимі реального часу (on-line).

Наступним етапом було навчити науково-педагогічних працівників університету вмінню та навичкам роботи в системі “Moodle”. Для цього упродовж двох місяців (грудень 2010 року - січень 2011 року) в комп’ютерних класах університету проводили семінаритренінги "Розробка та експлуатація електронних навчальних курсів у середовищі “Moodle”, на яких пройшли підготовку близько 120 викладачів.

Упродовж 2011 року співробітники університету наповнили сервер дистанційного навчання (СДН) електронними навчально-методичними матеріалами. Мультимедійні можливості LMS “Moodle” дозволили викладачам максимально унаочнити навчальний матеріал у вигляді навчальних таблиць, презентацій лекцій, відеороликів тощо. Це дає змогу посилити інтерес студентів до навчального матеріалу, поліпшити його засвоєння, а на практичному (семінарському) занятті оптимальніше використати відведений час. Крім того, мультимедійні ресурси дозволяють студентам вже на етапі підготовки до навчального заняття ознайомитися 3 3D-анатомічними моделями, у відеорежимі побачити методики проведення клінічного чи лабораторно-інструментального обстеження пацієнта, хід виконання експериментів, оперативних втручань, прослухати аудіолекції.

Важливим етапом підготовки студента до практичного заняття є самоконтроль. Для цього в електронних навчальних курсах у кінці кожного тематичного розділу створено елемент "Тестові завдання для самоконтролю”, які дають можливість студенту самостійно пройти тестування в режимі реального часу (online). Тестування можливе в навчальному (тренінговому) та контролюючому режимах. Після завершення тестування студент може побачити власну оцінку і правильність своїх відповідей. Викладач має змогу перевірити результати тестування студентів, побачити кількість спроб та затрачений час, визначити “найлегші” та “проблемні” для студентів тестові завдан- ня. Останнє дозволяє викладачу напередодні проведення навчального заняття адаптувати план його проведення, а саме вірно визначити акценти як в розрізі групи, так і в розрізі конкретного студента, що дозволяє індивідуалізувати навчальний процес.

Створення та удосконалення існуючих електронних навчальних курсів здійснюють на постійній основі. Станом на 01.03.2012 року на СДН експлуатують 1420 електронних навчальних курсів, загальний об'єм яких складає близько 500 Гб інформації. Окремо слід зазначити, що окрім україномовних ресурсів на сервері розміщено понад 90 електронних навчальних курсів англійською мовою, оскільки в університеті навчається майже 700 іноземних громадян.

У даний час на СДН зареєстровано майже 4800 користувачів, з них - близько 4500 студентів, лікарів(провізорів)-інтернів та лікарів-курсантів, які шляхом авторизації мають цілодобовий та безкоштовний доступ до електронних навчально-методичних матеріалів у мережі “Інтернет”.

На СДН широко використовують різноманітні форми зворотного зв'язку (форум, чат, система приватних повідомлень). На головному форумі обговорюються питання експлуатації електронних навчальних курсів, викладачі діляться досвідом створення мультимедійних чи інтерактивних ресурсів тощо. Студенти мають змогу висловити зауваження чи пропозиції стосовно якості та повноти навчальних матеріалів. На курсових форумах викладачі разом зі студентами обговорюють актуальні питання теоретичної та клінічної медицини. Чат дає змогу в режимі реального часу поспілкуватися великій кількості користувачів (студенти та викладачі) на поточні теми.

Потужний арсенал навчально-методичних ресурсів, інтерактивні елементи, гнучка та цікава система зворотного зв'язку перетворила СДН з навчальної вебплатформи на своєрідну соціальну мережу університетської спільноти. Свідченням цього може бути статистика відвідування сервера, згідно 3 якою його відвідують в середньому 2500 користувачів на день.

Популярність СДН сприяла позиціям БДМУ у рейтингу "Webometrics Ranking of World's Universities", який визначає місця університетів світу за показником їх наявності в мережі “Інтернет”. У липні 2011 року БДМУ увійшов до 5000 кращих університетів світу, посівши 18-ту сходинку серед ВНЗ України та 2-гу серед вищих медичних навчальних закладів.

Тестувальні елементи LMS “Moodle” активно використовують при підготовці до ліцензійних іспитів “Крок”. Для цього на СДН створено спеціальні електронні навчальні курси, в яких студенти, що атестува- 
тимуться в поточному навчальному році, опрацьовують профільні бази тестових завдань та екзаменаційні буклети минулих років. Ці курси адмініструють спеціально визначені відповідальні особи, які здійснюють моніторинг стану підготовки студентів до ліцензійних іспитів, своєчасно оновлюють банки тестових завдань, аналізують успішність вирішення тестових завдань у розрізі навчальних дисциплін. За результатами моні- торингу виявляють студентів, які мають загрозу не скласти ліцензійний іспит (“група ризику”), для них розробляють окремий план підготовки до іспиту. Такий підхід дозволив істотно поліпшити результати складання ліцензійних іспитів студентами та лікарямиінтернами БДМУ. На це вказує порівняння середнього відсотка правильних відповідей студентів БДМУ в 2011 році із національним показником (табл. 1).

Таблиця 1. Порівняння результатів складання студентами Буковинського державного медичного університету ліцензійних іспитів “Крок” у 2011 році із національним показником

\begin{tabular}{|c|c|c|}
\hline Назва ліцензійного іспиту & Національний показник & БДМУ \\
\hline Крок-1. Загальна лікарська підготовка & 68,6 & 72,4 \\
\hline Крок-1. Стоматологія & 67,7 & 69,3 \\
\hline Крок-2. Загальна лікарська підготовка & 91,8 & 90,1 \\
\hline Крок-2. Стоматологія & 79,1 & 78,0 \\
\hline Крок-2. Фармація & 86,2 & 90,3 \\
\hline Крок-3. Загальна лікарська підготовка & 78,6 & 79,4 \\
\hline
\end{tabular}

Як видно $з$ даних таблиці 1, результати складання студентами та лікарями-інтернами БДМУ ліцензійних іспитів “Крок” в 2011 році у більшості випадків переважають над національним показником, що вказує на ефективність використання IКТ при підготовці студентів до державної атестації. Крім того, прове-

Таблиця 2. Порівняння результатів складання студентами Буковинського державного медичного університету ліцензійних іспитів “Крок” у 2011 році із результатами роботами на сервері дистанційного навчання (СДН)

\begin{tabular}{|c|c|c|}
\hline Назва ліцензійного іспиту & Результат складання іспиту & Результат на СДН БДМУ \\
\hline Крок-1. Стоматологія & 69,3 & 69,7 \\
\hline Крок-1. Загальна лікарська підготовка & 72,4 & 78,7 \\
\hline Крок-2. Загальна лікарська підготовка & 90,0 & 87,1 \\
\hline Крок-2. Стоматологія & 78,0 & 77,6 \\
\hline Крок-2. Фармація & 90,3 & 82,6 \\
\hline Крок-3. Загальна лікарська підготовка & 79,4 & 81,9 \\
\hline
\end{tabular}

Висновки. У Буковинському державному медичному університеті впроваджені та успішно використовуються сучасні інформаційно-комунікаційні технології підтримки навчального процесу, що дозволило поліпшити якість підготовки фахівців на до- та дений аналіз зробив сильні прямі кореляційні зв’ язки між результатами роботи студентів на СДН та результатами складання ліцензійних іспитів $(\mathrm{r}=+0,69 \ldots+0,87)$. Порівняння результатів складання ліцензійних іспитів та результатів тестування на СДН представлено в таблиці 2. післядипломному етапах навчання. Система управління навчання "Moodle" сприяє удосконаленню та оптимізації процесу підготовки студентів та лікарівінтернів до навчальних занять, робить його більш комфортним, доступним, контрольованим та ефективним.

\section{Лiтература}

1. Пожуєв В. І. Інформатизація як ресурс розвитку сучасного українського суспільства / В. І. Пожуєв // Гуманітарний вісник Запорізької державної інженерної академії. -2009. - Вип. 38. - С. 4-12.

2. Морзе Н. В. Моделі ефективного використання інформаційно-комунікаційних та дистанційних технологій навчання у вищому навчальному закладі [Електронний ресурс] / Н. В. Морзе, О. Г. Глазунова // Інформаційні технології і засоби навчання. - 2008. - № 2(6). - Режим доступу до журн.: http://www.ime.edu-ua.net/em6/emg.html.

3. Бацуровська І. В. Використання дистанційних технологій в умовах кредитно-модульної системи організації навчання у вищих навчальних закладах [Електронний ресурс] / І. В. Бацуровська // Теорія та методика управління освітою. - 2011. - Вип. 6. - Режим доступу до журн.: http:/ /tme.umo.edu.ua/docs/6/11bathso.pdf

4. Національна стратегія розвитку освіти в Україні на 2012-2021 роки [Електронний ресурс]. - Режим доступу http://www.mon.gov.ua/images/files/news/12/05/4455.pdf

5. Голощук Р. О. Використання програмно забезпечення Moodle та Adobe для організації електронного навчання / Р. О. Голощук, О. О. Довбуш // Інформаційні системи та мережі : [збірник наукових праць]. - Львів, 2010. C. 249-258. 